\title{
EFFECT OF TRITICALE GRAIN CHARACTERISTICS, SCOURING, AND EXTRUSION CONDITIONS ON PHYSICO-CHEMICAL PROPERTIES, ANTIOXIDANT ACTIVITY, AND VOLATILE COMPOUNDS OF FLAT BREAD
}

\author{
W. Obuchowski ${ }^{\mathrm{a}}$, A. MakowsKa ${ }^{\mathrm{a}}$, S. Mildner-SzKudLarz ${ }^{\mathrm{a}}$, A. SzWengieL ${ }^{\mathrm{a}}$, \\ M. MAJCHER ${ }^{a}$ and M. REMISZEWSKI $I^{b}$

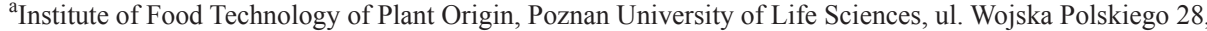 \\ 60-637 Poznan. Poland \\ ${ }^{a}$ Institute of Agricultural and Food Biotechnology, Rakowiecka 36 Warsaw. Poland
}

(Received: 7 April 2014; accepted: 8 July 2014)

\begin{abstract}
The objective of the study was to determine the effect of grain preparation technology, extrusion cooking conditions, and triticale cultivars on physico-chemical properties of crisp bread. Triticale cultivars used in the experiments differed in protein content, starch content, amylolytic activity, and viscosimetric properties. The type of the twinscrew extruder used has an effect on starch degradation, phenolic contents, and antioxidant activity of the product, but a greater effect on those characteristics is found for grain scouring prior to extrusion. All factors had an effect on volatile compound amounts in crisp bread, but the direction and range of these changes were random in character. Results of this study show that triticale grain can be useful raw material for the production of flat bread.

Keywords: triticale, grain scouring, extrusion-cooking, phenolic compounds, volatile compounds
\end{abstract}

Poland is a main producer of triticale grain in the world with its production of about 4.2 million ton in 2012, but that crop continues to be used as forage, not as food component. Recent advances in breeding of this crop have made triticale grain a valuable source of food for healthy human nutrition (MARCINIAK et al., 2008). Triticale compared to wheat cultivars contains twice more phytic acid (PlaAmI, 1997) and it is also a rich source of phenolics (PCs) and dietary fibres (DF). More than $90 \%$ of the phenolic acids in triticale cultivars are found in the form of ferulic acid (Hosseinian \& MazzA, 2009). The total dietary fibre content (TDF) and soluble dietary fibre (SDF) in triticale varieties grain are similar to in wheat and lower than in rye (RAKHA, 2011). The most outer tissues are rich in insoluble dietary fibre (IDF).

From the nutritional point of view, not only the TDF content but the ratio of SDF to IDF fractions is very important. The recommended proportion of IDF/SDF is 4:1 to 3:1 (GóRECKA et al., 2011). In triticale grain the ratio is about 6:1 (RAKHA, 2011). Removal of the most outer layer of grain improves that ratio (Овисношsкі et al., 2011).

Triticale flour is not a favoured raw material for loaf bread production, but it can be valuable material for the production of extruded goods. Grain scouring and extrusion cooking conditions have great effects on quality attributes of extruded goods. However, there is a limited body of information indicating which extrusion conditions, especially the type of the twin-screw extruder (co-rotating vs. counter-rotating), provide greater conversion of the raw material basic components as well as how far and in what direction they are changed.

\footnotetext{
* To whom correspondence should be addressed. Phone: +4861 84872 72; fax: +4861 84873 14; e-mail: mildners@up.poznan.pl
} 
The present study was designed to investigate the potential use of triticale cultivars and incorporate them into extruded crisp bread. The effect of grain preparation technology prior to extrusion cooking and extrusion conditions on physico-chemical properties of triticale crisp bread were also assessed as the main objective of the study.

\section{Materials and methods}

\subsection{Grain materials}

Grain of two triticale cultivars, i.e. cv. Pizarro and Leontino, obtained from the DANKO Plant Testing Station, harvest year 2010, were used in the experiments. Additionally, commercial corn grits and salt were used as additives in the production of flat bread.

One batch $(200 \mathrm{~kg}$ ) of grain of each triticale cultivar was intensely (up to $8 \%$ of the total mass) scoured before grinding in Vertical Hulling Machine VSM 250 (Streckel \& Schrader). The other $200 \mathrm{~kg}$ of grain were ground in an identical manner without scouring. Each batch was ground to grits size optimal for extrusion cooking, i.e. 1.5-3.0 mm.

\subsection{Extrusion process}

Crisp bread was produced using two different types of twin screw cooking extruders: corotating (Clextral BC-45) and counter-rotating (Metalchem 2S 9/5). The efficiency of extruders was similar $\left(70-100 \mathrm{~kg} \mathrm{~h}^{-1}\right)$. Retention time of the material passing through extruders was about $30 \mathrm{~s}$. The temperature of the process was between $130-180{ }^{\circ} \mathrm{C}$ in the co-rotating and $130-220^{\circ} \mathrm{C}$ in the counter-rotating twin-screw extruders, respectively. After the process, the extruded material was calibrated between two rolls, and cut into pieces of $50 \times 120 \times 5 \mathrm{~mm}$ in size. Pieces of bread were next dried to moisture content of about $4-5 \%$.

\subsection{Analytical methods}

1.3.1. Chemical and rheological characteristics. Grain of triticale cultivars were analysed for the falling number, moisture, protein, ash, and starch contents according to the methods of AACC (2000).

TDF, SDF, and IDF contents were determined according to the Asp method (AsP et al., 1983). PCs and antioxidant activity (AA) were assayed according to SINGLETON and RossI (1965) and RE and co-workers (1999), respectively. Pasting properties were evaluated using a Rapid Visco Analyser (RVA) (AACC, 2000). The Water Solubility Index (WSI) of samples was evaluated according to ANDERSON and co-workers (1969).

1.3.2. Water Extractable Saccharides (WES). WES were assayed according to the GPC method. HPLC analyses were performed on a Waters UltrahydrogelTM SEC column with a

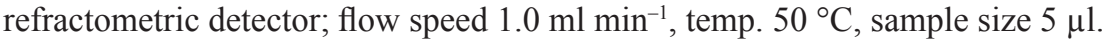

1.3.3. Volatile compounds analysis. The samples were frozen in liquid nitrogen and mechanically grated. They were placed in vials, and at the same time an internal standard, $\left[{ }^{2} \mathrm{H}_{6}\right]$-phenol, was added. Volatiles were sampled for $45 \mathrm{~min}$ at $50{ }^{\circ} \mathrm{C}$ from the headspace of the vial using DVB/CAR/PDMS fibre. Compounds were identified using the $\mathrm{GC} \times \mathrm{GC}$ system 
(Pegasus IV, LECO, St. Joseph, IL, USA) equipped with a DB-5MS (25 $\mathrm{m} \times 0.2 \mathrm{~mm}, 0.33$ $\mu \mathrm{m})$ column (Agilent J\&W, USA) coupled to a Supelcowax-10 $(1 \mathrm{~m} \times 0.1 \mathrm{~mm}, 0.1 \mu \mathrm{m})$ column (Supelco, Bellefonte, PA USA) running in a comprehensive multidimensional gas chromatography mode according to the method described by MAJCHER and co-workers (2010).

\subsection{Statistical analysis}

All experiments were performed in triplicate. Significant differences between samples were calculated using Statistica 10.0 PL software (StatSoft Tulsa, USA) at a significance level of $\mathrm{P}<0.05$. Analysis of variance (ANOVA) with the Duncan test was performed to determine the differences.

\section{Results and discussion}

Grain of triticale cultivars Leontino and Pizarro differed in protein and starch contents and particularly in the amylolytic parameter (Table 1). Cultivar Leontino is characterised by high protein and TDF contents and very low value of the falling number $(74 \mathrm{~s})$. More particular differences between Leontino and Pizarro were shown by viscosymetric analysis (Fig. 1). Except for a lack of significant differences in the initial temperature of starch pasting, the other properties were considerably different. Viscosity of dough made from Pizarro grain flour was almost 6 times higher than that of Leontino. Temperature of maximum viscosity for Pizarro was $95{ }^{\circ} \mathrm{C}$ and for Leontino only $76^{\circ} \mathrm{C}$. It suggests that Leontino starch is much more susceptible to pasting than that of Pizarro.

\begin{tabular}{|c|c|c|c|c|c|c|c|c|}
\hline Triticale & $\mathrm{Ash}^{* *}$ & Protein $^{* *}$ & Starch $^{* *}$ & $\begin{array}{l}\text { Gluten } \\
\text { yield }^{* *}\end{array}$ & $\begin{array}{c}\text { Falling } \\
\text { number }^{* * *}\end{array}$ & $\mathrm{TDF}^{* *}$ & $\mathrm{SDF}^{* *}$ & $\begin{array}{c}\text { IDF:SDF } \\
\text { ratio }\end{array}$ \\
\hline \multirow[t]{2}{*}{ Leontino } & $17.5^{\mathrm{a}}$ & $145^{\mathrm{b}}$ & $675^{\mathrm{b}}$ & $240^{\mathrm{b}}$ & $74^{\mathrm{a}}$ & $141.2^{b}$ & $19.2^{\mathrm{b}}$ & $6.3: 1$ \\
\hline & & & & & & $100.0^{\mathrm{a}^{*}}$ & $16.7^{\mathrm{a}^{*}}$ & $5.0: 1^{*}$ \\
\hline \multirow[t]{2}{*}{ Pizarro } & $18.2^{\mathrm{a}}$ & $123^{\mathrm{a}}$ & $700^{\mathrm{a}}$ & $200^{\mathrm{a}}$ & $245^{\mathrm{b}}$ & $123.1^{\mathrm{a}}$ & $17.6^{\mathrm{a}}$ & $6.0: 1$ \\
\hline & & & & & & $118.1^{b^{*}}$ & $18.5^{\mathrm{a}^{*}}$ & $5.4: 1^{*}$ \\
\hline
\end{tabular}

Means with the same letter in a row are not significantly different $(\mathrm{P}<0.05)$.

*: Result for scoured grain; **: expressed as $\mathrm{g} \mathrm{kg}^{-1} \mathrm{DM}$; ***: expressed as $\mathrm{S}$

The ratio of IDF/SDF in triticale grain was 6:1. After grain scouring, this ratio was improved (5:1) (Table 1). Grain scouring and discarding from the mill stream up to $10 \%$ of white flour, apart from slightly decreasing the total content of fibre, improved markedly the ratio of SDF to IDF. 


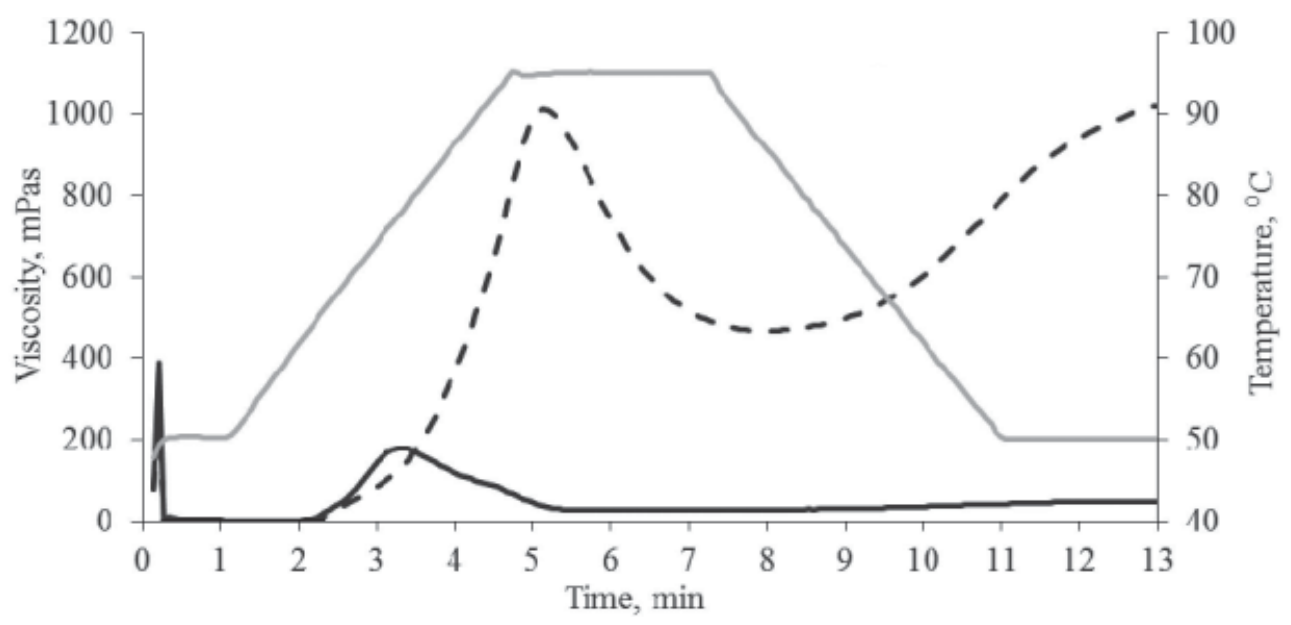

Fig. 1. Comparison of pasting properties of triticale raw material: Pizarro and Leontino -..-- Pizarro; —— Leontino; —— Temperature

The results in Table 2 show that both triticale grain scouring and the type of the extruder could greatly modify nutritional characteristics and quality attributes of flat bread. Grain scouring had a decreasing effect on PCs and antioxidative properties, due to the location of the most PCs in outer parts of the grain. The level of PCs ranged from 0.516 to $0.773 \mathrm{mg}$ $\mathrm{FAE} / \mathrm{g}$ DM. The results showed that the decreasing of PCs in flat bread produced in the corotating twin-screw extruder was significantly higher $(41 \%)$ than in the counter-rotating twin-screw extruder (25\%). Moreover, the reduction of PCs was lower in samples produced from not scoured grain. Extrusion has a positive effect on the AA of the product. After extrusion, crisp bread showed AA higher by 1.68 to $44 \%$ compared to the raw material. Our results are in agreement with the observation of CAPUANO and co-workers (2009), who also found an increased AA after toasting of crisp bread, and MARCINIAK and co-workers (2008), for extruded triticale bran. As a result of the Maillard reaction high amounts of very powerful antioxidants seem to be formed in crisp bread during extrusion. Antioxidants formed during the process may be mainly melanoidins or structures bound to those, such as pronyllysine (MAnzocco et al., 2001). Thus, the results seem to indicate that both melanoidins and the other natural antioxidants may be responsible for the scavenging activity of crisp bread. 
Table 2. The effect of grain scouring and type of extruder used on PCs, AA, WSI, and relative share of WES of raw material and extruded bread obtained from two different types of Triticale

\begin{tabular}{|c|c|c|c|c|c|c|c|}
\hline \multirow[t]{2}{*}{ Triticale } & \multirow[t]{2}{*}{$\begin{array}{l}\text { Grain preparation } \\
\text { before grinding }\end{array}$} & \multirow{2}{*}{$\begin{array}{c}\text { PCs } \\
\text { (mg FAE } \\
\mathrm{g}^{-1} \text { d.m.) }\end{array}$} & \multirow{2}{*}{$\begin{array}{c}\text { AA } \\
(\mu \mathrm{g} \text { TRE } \\
\left.\mathrm{g}^{-1} \text { d.m. }\right)\end{array}$} & \multirow{2}{*}{$\begin{array}{l}\text { WSI } \\
\text { ( } \mathrm{g} \mathrm{kg}^{-1} \\
\text { d.m.) }\end{array}$} & \multicolumn{3}{|c|}{$\begin{array}{c}\text { Ratio of water extractable } \\
\text { polysaccharides }(\%)\end{array}$} \\
\hline & & & & & $\mathrm{DP}>3000$ & $\begin{array}{c}3000>\mathrm{DP} \\
>10\end{array}$ & $\mathrm{DP}<10$ \\
\hline \multicolumn{8}{|c|}{ Raw materials (Triticale grits) } \\
\hline \multirow[t]{2}{*}{ Leontino } & control & $0.838^{\mathrm{c}}$ & $42.90^{\mathrm{a}}$ & $95^{\mathrm{a}}$ & $15.5^{\mathrm{b}}$ & $18.3^{\mathrm{c}}$ & $66.1^{\mathrm{j}}$ \\
\hline & scoured grain & $0.764^{\mathrm{d}}$ & $35.50^{\mathrm{b}}$ & $88^{\mathrm{a}}$ & $16.0^{\mathrm{b}}$ & $25.7^{\mathrm{e}}$ & $58.4^{\mathrm{i}}$ \\
\hline \multirow[t]{2}{*}{ Pizarro } & control & $1.013^{\mathrm{a}}$ & $43.53^{\mathrm{a}}$ & $97^{\mathrm{a}}$ & $6.2^{\mathrm{a}}$ & $45.5^{\mathrm{g}}$ & $48.3^{\mathrm{g}}$ \\
\hline & scoured grain & $0.941^{\mathrm{b}}$ & $38.13^{\mathrm{b}}$ & $88^{\mathrm{a}}$ & $10.1^{\mathrm{ab}}$ & $28.7^{\mathrm{ef}}$ & $61.2^{\mathrm{i}}$ \\
\hline \multicolumn{8}{|l|}{ Flat bread } \\
\hline \multicolumn{8}{|c|}{ Co-rotating extruder } \\
\hline \multirow[t]{2}{*}{ Leontino } & control & $0.657^{\mathrm{b}}$ & $53.03^{\mathrm{b}}$ & $396^{\mathrm{b}}$ & $61.2^{\mathrm{i}}$ & $22.7^{\mathrm{de}}$ & $16.1^{\mathrm{b}}$ \\
\hline & scoured grain & $0.569^{\mathrm{d}}$ & $44.63^{\mathrm{d}}$ & $419^{\mathrm{bc}}$ & $47.3^{\mathrm{g}}$ & $22.0^{\mathrm{d}}$ & $30.6^{\mathrm{f}}$ \\
\hline \multirow[t]{2}{*}{ Pizarro } & control & $0.773^{\mathrm{a}}$ & $48.90^{\mathrm{c}}$ & $438^{\mathrm{c}}$ & $46.1^{\mathrm{g}}$ & $22.7^{\mathrm{de}}$ & $16.1^{\mathrm{b}}$ \\
\hline & scoured grain & $0.658^{\mathrm{b}}$ & $38.83^{\mathrm{e}}$ & $470^{\mathrm{c}}$ & $26.8^{\mathrm{e}}$ & $51.7^{\mathrm{h}}$ & $21.5^{\mathrm{d}}$ \\
\hline \multicolumn{8}{|c|}{ Counter-rotating extruder } \\
\hline \multirow[t]{2}{*}{ Leontino } & control & $0.614^{\mathrm{c}}$ & $61.97^{\mathrm{a}}$ & $461^{\mathrm{c}}$ & $68.6^{\mathrm{j}}$ & $17.7^{\mathrm{bc}}$ & $13.7^{\mathrm{b}}$ \\
\hline & scoured grain & $0.409^{\mathrm{f}}$ & $46.13^{\mathrm{d}}$ & $569^{\mathrm{d}}$ & $74.7^{\mathrm{h}}$ & $11.3^{\mathrm{ab}}$ & $14.0^{\mathrm{b}}$ \\
\hline \multirow[t]{2}{*}{ Pizarro } & control & $0.516^{\mathrm{a}}$ & $44.27^{\mathrm{d}}$ & $448^{\mathrm{c}}$ & $69.9^{j}$ & $15.1^{\mathrm{b}}$ & $15.1^{\mathrm{b}}$ \\
\hline & scoured grain & $0.532^{\mathrm{e}}$ & $43.60^{d}$ & $573^{d}$ & $60.1^{\mathrm{i}}$ & $21.0^{\mathrm{d}}$ & $18.9^{\mathrm{c}}$ \\
\hline
\end{tabular}

Means with the same letter in a raw are not significantly different $(\mathrm{P}<0.05)$.

The extrusion process had the greatest effect on physico-chemical properties of the extruded products (Table 2). In comparison to the raw material, the WSI of flat bread was four times higher. WSI is often treated as an indicator of the amount of oligosaccharides (OS), produced especially from starch degradation during the extrusion process (Lazou \& KROKIDA, 2010). Bread obtained from the counter-rotating extruder showed higher WSI values in comparison to the application of the co-rotating extruder, but the effect could be connected not only with shear, but the higher temperature of the process in the counterrotating extruder. Moreover, higher WSI values were obtained in the case of the extrusion cooking process of grain from cv. Leontino than from Pizarro. The GPC analysis of the relative share of WES (fractions of DP of 1-10, 10-3000, and above 3000) show higher amounts of low molecular OS (retention time of $38-45 \mathrm{~min}$ ) in the raw material in comparison to extruded bread (Table 2, Fig. 2). The WES profile in the raw materials was dominated by OS of DP 1-10 (48-66\%) with small amount of high molecular weight polysaccharides (6$16 \%$ ). Extrusion caused a relative increase in the ratio of high molecular WES fraction. There are also differences in the OS composition in the bread obtained from two types of extruders: bread from the counter-rotating extruder is richer in high molecular water soluble OS (retention time 15-25 min) in comparison to bread produces in co-rotating device. This confirms that in that type of extruder the physico-chemical processing of material is more 
intensive and the degree of starch degradation to dextrin is higher. There was no significant effect of grain scouring and extrusion or the triticale cultivar on the amount of OS with DP below 10. Those results indicate that extrusion in both extruders leads to considerable starch degradation, but only to high molecular polysaccharides, and has no effect on the amount of low molecular OS.
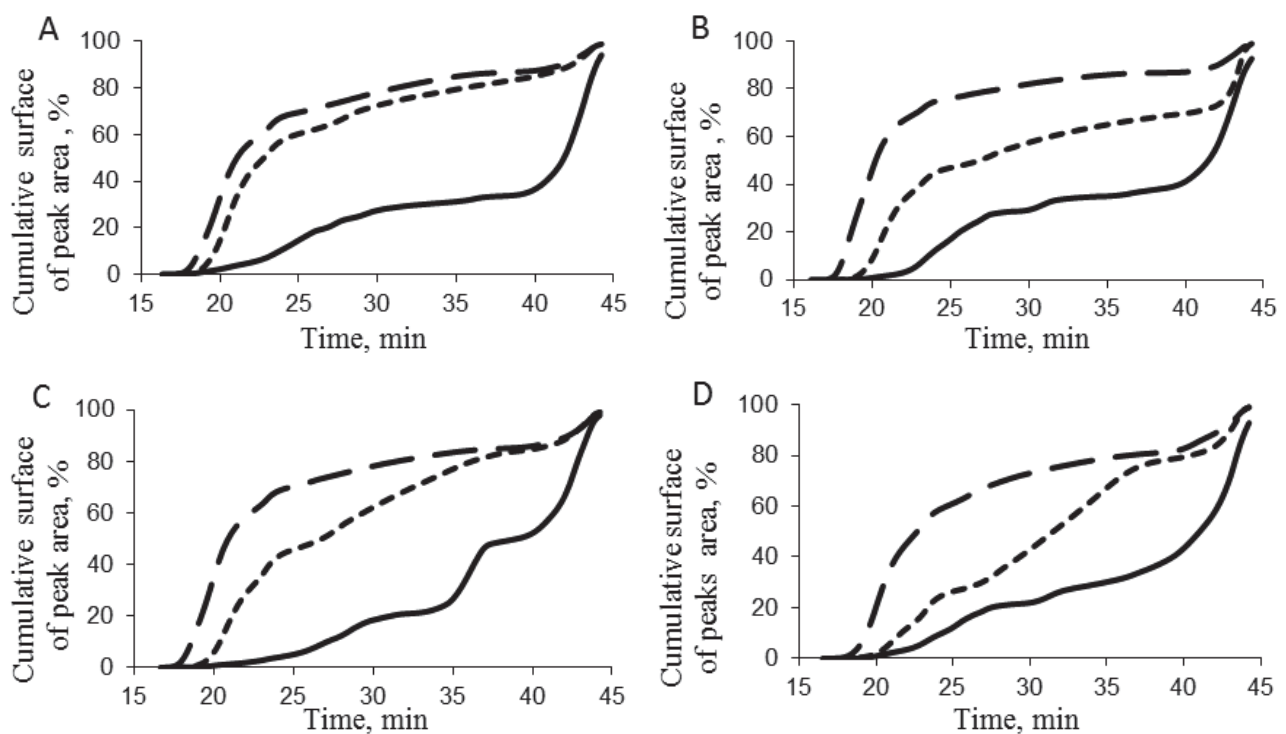

Fig. 2. Cumulative weight fraction of low molecular water extractable oligo- and poly-saccharides from raw materials and flat bread ( - : raw material; ----: co-rotating extruder; — - : counter-rotating extruder; A: Leontino, whole grain; B: Leontino, scoured grain; C: Pizarro, whole grain; D: Pizarro, scoured grain)

Several volatile components that contribute to the aroma profile of raw materials and flat breads using SPME-GCxGC/TOF-MS are listed in Table 3. These compounds included sulphur compounds, aldehydes, alcohols, ketenes, and pyrazines. The most abundant volatiles found in the headspace of analysed samples were aldehydes. These compounds contributed to nearly $63 \%$ and $75 \%$ of total amount of volatiles in raw materials and flat breads, respectively. Hexanal was the predominant aldehyde; it should be pointed out that heat treatment process provokes its formation. Grain scouring caused a decrease in the amount of almost all aroma compounds in the bread, which indicates that mostly compounds of the pericarp of triticale kernels are responsible for the aroma of extruded bread. Nevertheless, volatile compounds of crisp bread were relatively much more intense in comparison with those of the raw material. Generally, after extrusion process, formation of volatile compounds for crisp bread obtained from scoured and unscoured grain was about 4-fold and 2-fold higher than for raw materials, respectively. From 15 compounds identified in extruded samples 4 were not present in the grain of triticale cultivars Leontino and 3 were not present in the grain of cultivars Pizarro; therefore, they may be formed during the extrusion process. These compounds were methanethiol, methional, dimethyl trisulphide, (E,E)-2,4-decadienal and 2-ethyl-3,5-dimethyl pyrazine. Methanethiol and 2,2-methional are formed during the heating 
OBUCHOWSKI et al.: CHARACTERISTICS OF TRITICALE EXTRUDED FLAT BREAD

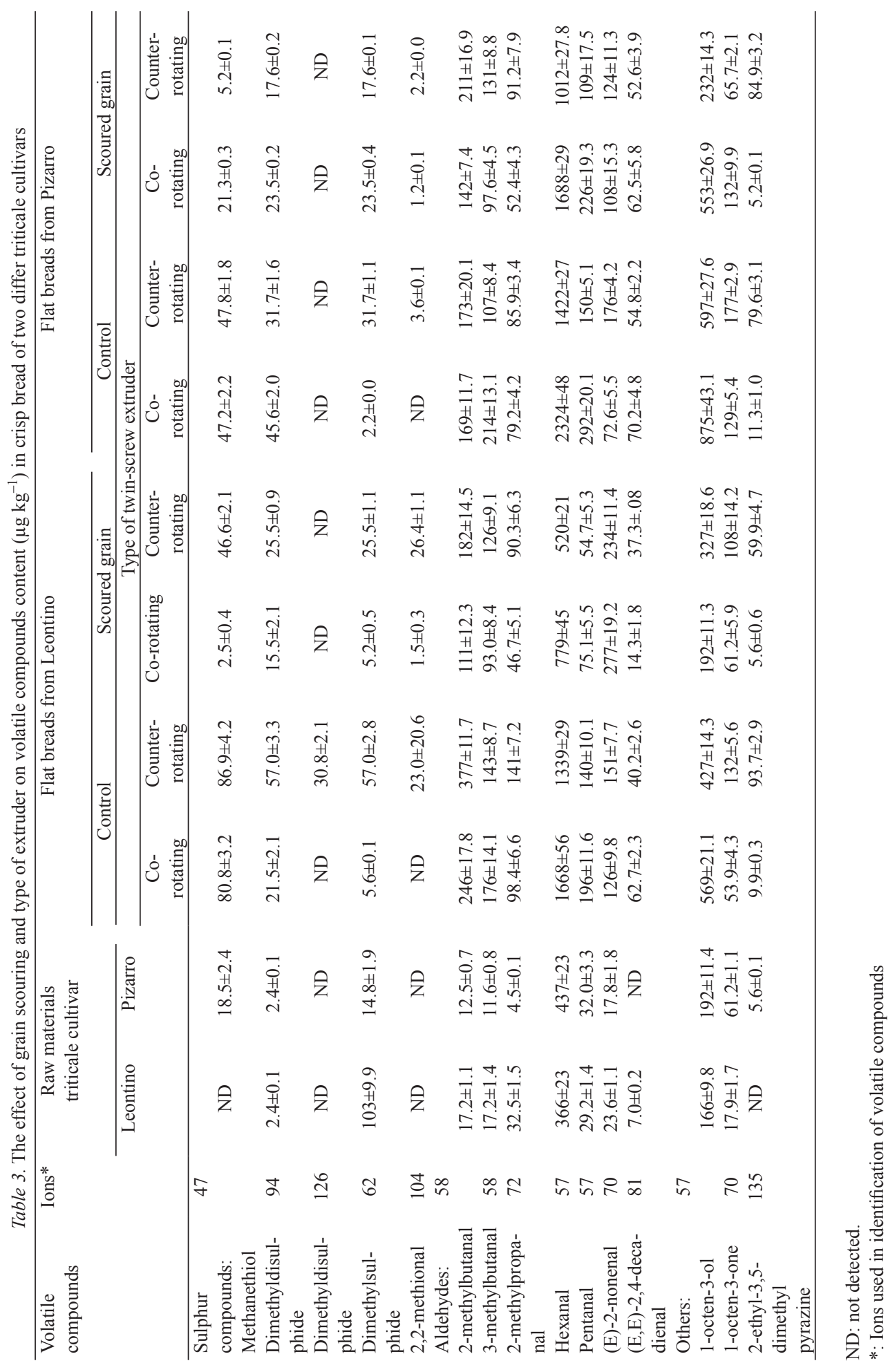


of food from Strecker degradation of the amino acid-methionine (BeLITZ et al., 2004). Dimethyl trisulphide is formed indirectly in the Strecker degradation of methionine through methional and dimethyl disulphide. 2-Ethyl-3,5 dimethylpyrazine, formed from Maillard reaction of alanine and 2-oxopropanal, is characterized as key contributor to the flavour of processed food products such as popcorn, rye bread crust, or roasted wild mango fruit. It was found that the type of extruder had also effect on the aroma compounds profile. Higher amounts of sulphur compounds and most changes in the amount of aldehydes were obtained in the crisp bread produced in counter-rotating extruder, probably as an effect of a little $\left(10^{\circ} \mathrm{C}\right)$ higher temperature in that type of extruder in comparison to extrusion process realized in co-rotating extruder. A certain effect of the triticale cultivar on the amount of other aroma compounds was also found, but the differences in each compound were inconsequent.

\section{Conclusions}

Results of this study show that triticale grain can be useful raw material for extruded flat bread production. The type of twin-screw extruder used has an effect on starch degradation, as well as PCs and AA of the product. However, a greater effect on those characters was found for grain scouring prior to extrusion. In the case of using the twin-screw extruder in the production process, triticale grain characteristics, expressed by the falling number and viscous properties, have a minor effect on WSI. All factors: triticale cultivar, grain scouring, and type of extruder had an effect on volatile compound amounts in crisp bread, but direction and the range of changes were random in character. Results recorded in that experiment show that it is possible to produce high quality crisp bread with good nutritional value using selected triticale grain, equipment, and technology specifically adapted to that raw material. However, the raw material should be selected depending on the DF as well as PCs and AA.

This study was financially supported by the grant POIG 01.01.02-00-061/09 "Bioactive food" implemented within the Programme Innovative Economy 2007-2013.

\section{References}

AACC (2000): Approved Methods of Analysis, 11th Ed. AACC International, St. Paul, MN, USA. Methods: 5681.03, 46-10.01, 08-01.01, 44-19, 76-13.01, 76-21.

Anderson, R.A., Conway, H.F., Pfeifer, V.F. \& Griffin, E.L.J.R. (1969): Gelatinization of corn grits by roll and extrusion cooking. Cereal Sci. Today, 14, 11-12.

Asp, N.G., Johansson, C.G., Hallmer, H. \& Silijestrom, M. (1983): Rapid enzymatic assay of insoluble and soluble dietary fiber. J. Agric. Food Chem., 31, 476-482.

Belitz, H.-D., Grosch, W. \& Schieberle, P. (2004): Food chemistry. Springer, Berlin, Germany, 1071 pages.

Capuano, E., Ferrigno, A., Acampa, I., Serpen, A., Açar, Ö.Ç., Gökmen, V. \& Fogliano, V. (2009): Effect of flour type on Maillard reaction and acrylamide formation during toasting of bread crisp model systems and mitigation strategies. Food Res. Int., 42, 1295-1302.

Górecka, D., Janus, P., Borysiak-Marzec, P. \& Dziedzic K. (2011): Analiza spożycia błonnika pokarmowego i jego frakcji w Polsce w ostatnim dziesięcioleciu w oparciu o dane GUS (Analysis of consumption of dietary fibre and its fractions in Poland in the last decade based on CSO data). Probl. Hig. Epidemiol., 92, 703-706.

Hosseinian, F.S. \& Mazza, G. (2009): Triticale bran and straw: potential new sources of phenolic acids, proanthocyanidins, and lignans. J. Funct. Foods, 1, 57-64. 
Lazou, A. \& Krokida, M. (2010): Functional properties of corn and corn-lentil extrudates. Food Res. Int., 43, 609-616.

Majcher, M., Ławrowski, P. \& Jeleń, H. (2010): Comparison of original and adulterated oscypek cheese based on volatile and sensory profiles. Acta Sci. Pol. Technol. Aliment., 9(3), 265-275.

Manzocco, L., Calligaris, S., Mastrocola, D., Nicoli, M.C. \& Lerici, C.R. (2001): Review of non-enzymatic browning and antioxidant capacity in processed foods. Trends Food Sci. Tech., 11, 340-346.

Marciniak, A., Obuchowski, W. \& Makowska, A. (2008): Technological and nutritional aspects of utilisation of triticale for extruded food production. EJPAU, 11. (4), \#04. Available online: http://www.ejpau.media.pl/ volume11/issue $4 /$ art- 04. html

Obuchowski, W., Michniewicz, J., Makowska, A. \& Majcher, M. (2011): Sposób wytwarzania mąki o podwyższonej zawartości błonnika rozpuszczalnego przy jednoczesnym zmniejszeniu frakcji błonnika nierozpuszczalnego (Method for producing flours, involves subjecting grains to milling process, selecting grinding material, receiving fraction of ash content in range of percentages, and obtaining soluble fiber in range of certain percentages). Patent PL395819-A1.

PlaAmi, S.P. (1997): Content of dietary fiber in foods and its physiological effects. Food Res. Int., 13, 29-76.

RAKHA, A. (2011): Characterisation of dietary fibre in cereal grains and products. Emphasis on triticale and rye. Doctoral Thesis, Swedish University of Agricultural Sciences, Uppsala. 80 pages.

Re, R., Pellegrini, N., Proteggente, A., Pannala, A., Yang, T. \& Rice-Evans, C. (1999): Antioxidant activity applying an improved ABTS radical cation decolarization assay. Free Radical Bio. Med., 26, 1231-1237.

Singleton, V.L. \& Rossi, J.A. (1965): Colorimetry of total phenolics with phosphomolybdic acid reagents. Am. J. Enol. Vitic., 16, 144-158. 